\title{
ANALISIS DESAIN KEMASAN MI INSTAN EDISI KHUSUS INDOMIE TEMPO DOELOE
}

\author{
Yana Erlyana $^{1 *}$, Nadya $^{2}$ \\ ${ }^{1,2}$ Program Studi Desain Komunikasi Visual, Universitas Bunda Mulia, Jl. Lodan Raya No. 2 Ancol, \\ Jakarta Utara 14430, Indonesia
}

Diterima: 21 Febuari 2018/ Disetujui: 6 Maret 2018

\begin{abstract}
The purpose of this research is to analyze the packaging design of the Indomie Tempo Doeloe. This research uses visual attractiviness theory and practical appeal theory, hopping that results of this study particulary useful for designers and business people who will make similiar products.This research uses qualitative method which deliver descriptive data of packaging design and its information which is aligned with the theory and literature used. The results of research is the form of analysis of each packaging of Indomie Tempo Doeloe which consist of visual attractiveness analysis and practical appeal on every packgaging.
\end{abstract}

Keywords: Packaging Design, Instant Noodle, Indomie

\begin{abstract}
ABSTRAK
Tujuan dari penelitian ini adalah untuk menganalisis desain kemasan dari produk Indomie Tempo Doloe. Penelitian ini menggunakan teori daya tarik visual dan teori daya tarik praktis, dengan berharap hasil dari studi ini dapat menjadi berguna bagi desainer dan pebisnis yang akan membuat produk sejenis. Penelitian ini menggunakan metode kualitatif yang menyampaikan data dan informasi desain kemasan selurus dengan teori dan literatur yang digunakan. Hasil dari penelitian ini adalah bentuk analisis dari setiap kemasan Indomie Tempo Doloe yang mengandung analisis daya tarik visual dan daya tarik praktis.
\end{abstract}

Kata kunci: Desain Kemasan, Mie Instan, Indomie

\section{PENDAHULUAN}

Mi instan pertama kali diperkenalkan kepada masyarakat Indonesia pada tahun 1969. Banyak yang meragukan bahwa mi instan dapat dijadikan sebagai salah satu bahan pangan pokok. Tetapi mi instan memiliki harga yang relatif murah, terjangkau, awet dan mudah disajikan. Mulailah muncul produk-produk mi instan seperti Indomie. Indomie adalah salah satu produsen mi instan terbesar di Indonesia. Indomie adalah produk dibawah naungan PT Indofood Sukses Makmur Tbk, yang pada awalnya didirikan dengan nama PT Panganjaya Intikusuma. Indomie hadir sejak tahun 1972 dan diawal kehadirannya Indomie memperkenalan Indomie Kuah Rasa Kaldu Ayam (1972), lalu Indomie mengalami peningkatan yang sangat

\footnotetext{
*email: yerlyana@bundamulia.ac.id
}

signifikan dengan diluncurkannya varian baru yakni Indomie Kuah Rasa Kari Ayam (1980) serta Indomie Mi Goreng (1982). Indomie sangat berkembang dan populer di Indonesia. Seiring berjalannya waktu, Indomie bertambah populer bahkan mudah ditemukan walau di luar negeri sekalipun seperti, Saudi Arabia, Mesir, Malaysia, Australia, Amerika hingga Nigeria. Indomie merupakan produk mi instan yang sangat digemari di Indonesia hingga saat ini memiliki berbagai macam varian jenis produk dan varian jenis rasa. Kemasan dan rasa Indomie sejak awal dipasarkan juga mengalami beberapa perubahan mengikuti perkembangan dan selera pasar. 


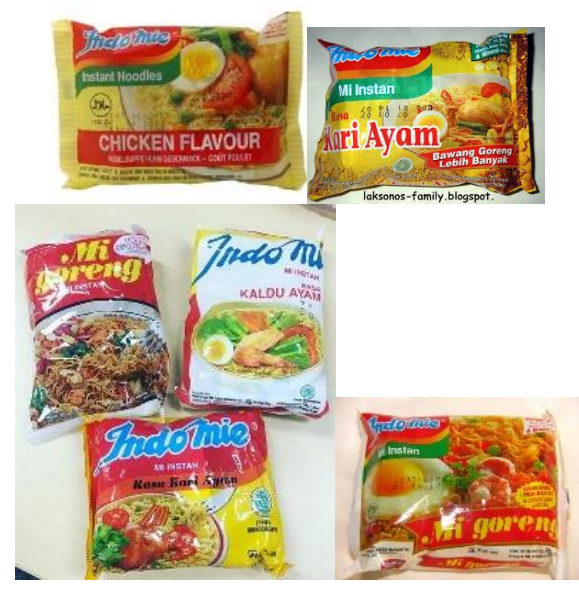

\section{Gambar 1 Evolusi Kemasan Indomie (Sumber: Data Internet, 2017)}

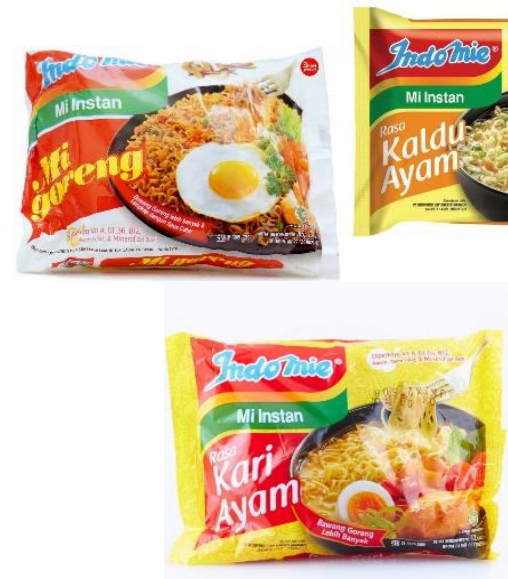

\section{Gambar 2 Kemasan Indomie Saat Ini (Sumber: Data Internet, 2017)}

Kemasan Indomie saat ini terlihat lebih sederhana, ringan dan menarik dibandingkan dengan kemasan-kemasan sebelumnya.

Salah satu cara bertahan pada arus persaingan industri adalah mengembangkan inovasi dan memberikan ide-ide menarik yang dapat memikat konsumen. Oleh sebab itu, dalam rangka memperingati HUT Indomie ke-45, Indomie meluncurkan produk Indomie spesial secara terbatas dengan tema tempo dulu. Indomie mengedarkan kembali produk Indomie dengan kemasan dan rasa yang sama dengan produk pertama kali diluncurkan. Indomie edisi ini disebut dengan 'Indomie Tempo Doeloe'. Inovasi seperti ini ditujukan untuk menarik perhatian pasar dan ingin bertahan di dalam persaingan industri dalam produk yang serupa. Tujuan utama strategi bersaing untuk sebuah unit bisnis dalam sebuah industri adalah menemukan posisi dalam industri tersebut di mana perusahaan dapat melindungi diri sendiri dengan sebaik-baiknya (Porter, 1998). Melalui latar belakang tersebut, peneliti bermaksud untuk melakukan analisis pada desain kemasan Indomie Tempo Doeloe melalui pendekatan dan teori daya tarik visual dan daya tarik praktis kemasan.

Adanya produk inovasi yang dikeluarkan oleh Indomie dengan nama 'Indomie Tempo Doeloe'.

Tujuan dan manfaat dari penelitian ini adalah untuk menganalisis desain kemasan produk Indomie Tempo Doeloe dengan pendekatan teori daya tarik visual dan daya tarik praktis. Adapun manfaat dari penelitian ini adalah agar dimasa depan semaikn banyak produk dalam negeri yang mau berusaha melakukan perkembangan dan memberikan ide-ide dalam hal perancangan desain kemasan.

\section{TINJAUAN PUSTAKA \\ Teori Kemasan}

Menurut Sri Julianti (2014:15), kemasan adalah wadah untuk meningkatkan nilai dan fungsi sebuah produk. Berdasarkan definisi tersebut, maka ada beberapa fungsi kemasan, yaitu:

a. Melindungi kualitas produk.

b. Membuat produk lebih tahan lama.

c. Sebagai sarana komunikasi produk dan branding kepada konsumen.

d. Membantu distribusi produk dari produsen sampai ke tangan konsumen.

e. Membuat produk dapat diproduksi secara massal.

f. Menjadi pemicu minat beli dengan merangsang lima panca indra konsumen, yaitu melihat, mendengar, membaui, merasa, sampai ada keputusan membeli dan menggunakan produk.

\section{Fungsi Kemasan}

Menurut Sri Julianti juga kemasan juga memiliki fungsi strategis yang sifatnya 
mampu memberikan positioning baru dan leverage atau daya ungkit bagi sebuah produk.

Berdasarkan fungsinya, kemasan dibagi menjadi dua, yaitu:

\section{- Kemasan Primer}

Kemasan primer adalah keseluruhan kemasan yang dipajang dan yang membuat konsumen memutuskan untuk membeli produk tersebut. Kemasan primer sangat penting dari segi fungsinya untuk melindungi (protection), komunikasi ke pelanggan (communication), dan termasuk fungsi artistik agar konsumen yang melihat langsung tertarik untuk membeli.

- Kemasan Sekunder

Kemasan sekunder (disebut juga transport packaging) diperlukan untuk melindungi kemasan primer selama dalam penyimpanan di gudang serta saat didistribusikan ke pelanggan partai besar maupun pelanggan eceran. Kemasan sekunder juga untuk mengatisipasi moda transportasi serta kondisi jalan pada sistem distribusinya. Kemasan sekunder merupakan satu kesatuan dengan primer. Pada kemasan primer yang menggunakan bahan fleksible, sering kali diperlukan kemasan sekunder yang lebih kuat untuk melindungi produk maupun kemasan primernya.

Berdasarkan material atau bahan bakunya, kemasan juga dapat dibagi menjadi beberapa macam, seperti:

- Natural/alam: daun, bambu dan kayu.

- Kertas dan karton, termasuk karton gelombang.

- Plastik dan rigid dan semi-rigid.

- Fleksibel.

- Gelas.

Logam: alumunium dan baja.

\section{Prinsip Desain Kemasan}

Ada banyak variabel yang memengaruhi bagaimana dan mengapa desain kemasan menarik konsumen. Periset konsumen menghabiskan waktu yang banyak untuk menganalisi variabel-variabel ini. Dari suatu perspektif desain murni (memindahkan variabel pemasaran lain seperti harga, lokasi, dan kesetiaan merek) terdapat elemen-elemen penting yang menangkap perhatian konsumen dengan sangat baik dan menerobos kerumunan visual dalam kompetisi ritel. (Klimchuk \& Krasovec, 2007:82)

Empat penarik perhatian utama suatu kemasan adalah:

1. Warna.

2. Struktur fisik atau bentuk.

3. Simbol dan angka.

4. Tipografi.

\section{Daya Tarik Kemasan}

Daya tarik kemasan dapat digolongkan menjadi 2 (dua), yaitu:

a. Daya Tarik Visual (Estetika)

Daya tarik visual mengacu pada penampilan kemasan yang mencakup unsur grafis (warna, bentuk, merek/logo, ilustrasi, huruf/tipografi, tata letak). Semua unsur grafis tersebut dikombinasikan untuk menicptakan suatu kesan untuk memberikan daya tarik visual secara optimal. Daya tarik visual sendiri berhubungan dengan faktor emosi dan psikologis.

b. Daya Tarik Praktis (fungsional)

Daya tarik praktis merupakan efektifitas dan efisiensi suatu kemasan yang ditujukan kepada konsumen maupun distributor, misalnya untuk kemudahan penyimpanan atau pemajangan produk. Faktor-faktor yang berkaitan dengan daya tarik praktis (fungsional) adalah sebagai berikut:

1. Faktor Pengamanan

Kemasan harus melindungi produk terhadap berbagai kemungkinan yang dapat menjadi penyebab timbulnya kerusakan barang, misalnya: cuaca, sinar matahari, jatuh, tumpukan, kuman, serangga dan lain-lain. Contohnya, kemasan biskuit yang dapat ditutup kembali agar kerenyahannya tahan lama. 
2. Faktor Ekonomi

Perhitungan biaya produksi yang efektif termasuk pemilihan bahan, sehingga biaya tidak melebihi proporsi manfaatnya. Contohnya, produk-produk re-fill atau isi ulang, produk-produk susu atau makanan bayi dalam karton.

3. Faktor Pendistribusian

Kemasan harus mudah didistribusikan dari pabrik ke distributor atau pengecer sampai ke tangan konsumen. Di tingkat distributor, kemudahan penyimpanan dan pemajangan perlu dipertimbangkan. Bentuk dan ukuran kemasan harus direncanakan dan dirancang sedemikian rupa sehingga tidak sampai menyulitkan peletakan di rak atau tempat pemajangan.

4. Faktor Komunikasi

Kemasan sebagai media komunikasi menerangkan dan mencerminkan produk, citra merek, dan juga bagian dari produksi dengan pertimbangan mudah dilihat, dipahami dan diingat. Misalnya, karena bentuk kemasan yang aneh sehingga produk tidak dapat "diberdirikan", harus diletakkan pada posisi "tidur" sehingga ada tulisan yang tidak dapat terbaca dengan baik, maka fungsi kemasan sebagai media komunikasi sudah gagal.

5. Faktor Ergonomi

Pertimbangan agar kemasan mudah dibawa atau dipegang, dibuka dan mudah diambil sangatlah penting. Pertimbangan ini selain mempengaruhi bentuk dari kemasan itu sendiri juga mempengaruhi kenyamanan pemakai produk atau konsumen. Contohnya, bentuk botol minyak goreng Tropical yang pada bagian tengahnya diberi cekungan dan tekstur agar mudah dipegang dan tidak licin bila tangan pemakainya terkena minyak.

6. Faktor Identitas

Kemasan secara keseluruhan harus berbeda dengan kemasan lain, memiliki identitas produk agar mudah dikenali dan dibedakan dengan produk-produk yang lain.

\section{Faktor Promosi}

Kemasan mempunyai peranan penting dalam bidang promosi, dalam hal ini Kemasan berfungsi sebagai silent sales person. Peningkatan kemasan dapat efektif untuk menarik perhatian konsumen-konsumen baru.

8. Faktor Lingkungan

Kita hidup di dalam era industri dan masyarakat yang berpikiran kritis. Dalam situasi dan kondisi seperti ini, masalah lingkungan tidak dapat terlepas dari pantauan kita. Trend dalam masyarakat kita akhir-akhir ini adalah kekhawatiran mengenai polusi, salah satunya pembuangan sampah. Salah satunya yang pernah menjadi topik hangat adalah styrofoam. Pada tahun 1990 organisasi-organisasi lingkungan hidup berhasil menekan perusahaan Mc Donalds untuk mendaur ulang kemasan-kemasan mereka. (Cenadi,1999:8).

\section{Warna}

Warna adalah salah satu aspek yang paling berpengaruh dari desain kemasan. Konsumen lebih mengidentifikasi warna kemasan atau produk sebelum fitur visual lainnya. Warna pada desain kemasan berfungsi untuk membedakan kepribadian, menarik perhatian ke atribut-atribut lainnya, dan untuk membuat perbedaan dari kompetitor.

Pertama, warna dapat digunakan sebagai identitas brand, sehingga konsumen dapat mengenal brand dengan mudah. Dengan berjalannya waktu, dan melalui penggunaan warna yang konsisten, sehingga ketika konsumen melihat sebuah warna dapat 
menjadi milik brand tersebut dan segera mengidentikan warna tersebut dengan sebuah brand. Contohnya seperti pepsi identik dengan warna biru dan coca-cola dengan warna merah. Kedua, warna dapat digunakan untuk membedakan varian produk dalam satu brand. Oleh karena itu warna menjadi kriteria visual penting yang mengasumsikan tingkat yang berbeda kepentingan tergantung pada jumlah diferensiasi yang dicapai oleh unsur-unsur lain dari kemasan.

Ketiga, warna banyak digunakan untuk membedakan merek produk satu dengan produk yang lain dalam satu barisan yang berdampingan. Pada ritel terdapat dua atau lebih produk dalam satu kelompok, contohnya makanan atau kosmetik. Merek utama memiliki warna untuk setiap jenis produk, sehingga konsumen dapat dengan mudah menyeleksi berbagai produk dan memungkinkan konsumen untuk membuat perbedaan yang lebih mudah dikenali serta menemukan produk yang tepat untuk kebutuhan mereka.

Jil Morton, konsultan warna dan CEO perusahaan ColorCom menyatakan, "Sebagai alat marketing, warna dapat menjadi kekuatan persuasif bawah sadar. Sebagai suatu komponen fungsional dari penglihatan manusia, warna dapat menarik perhatian, menyejukkan atau menyakitkan mata dan berkontribusi pada kesuksesan suatu produk, jasa atau bahkan suatu interior ruangan. Warna yang salah dapat menjadi kesalahan yang mahal."

(Calver, 2007:147-148).

\section{Ilustrasi}

Ilustrasi dilihat dari segi teknisnya dapat digolongkan menjadi beberapa teknik, yaitu:

- Ilustrasi Tangan

Yaitu teknik ilustrasi dengan cara mengandalkan keterampilan tangan sepenuhnya baik itu menggunakan kuas, pensil, pena, air brush dan alatalat menggambar lainnya. Ada beberapa guna dari ilustrasi tangan, yaitu sebagai simbolisasi, menggambarkan fantasi, menggambarkan sesuatu yang membangkitkan selera humor, untuk pengganti foto.
- Ilustrasi Fotografi

Yaitu teknik membuat gambar ilustrasi berupa foto dengan bantuan kamera baik itu manual maupun digital. Biasanya objek fotografi menjadi lebih realistis, eksklusif dan persuasif. Ilustrasi fotografi memiliki beberapa kegunaan, yaitu menggambarkan perbandingan, menunjukan berita, mengabadikan sesuatu, mencitrakan suasana hati, menggambarkan sesuatu yang membangkitkan rasa kemanusiaan (Suyanto, 2004:89).

- Teknik Gabungan

Yaitu ilustrasi bentuk komunikasi dengan struktur visual atau rupa yang terwujud dari perpaduan antara teknik fotografi/ilustrasi manual dengan teknik menggambar di komputer (Pujiriyanto, 2005:41).

\section{Metode Penelitian}

Penelitian ini menggunakan metode kualitatif dimana dilakukan analisis berdasarkan teori-teori yang terkait dengan sumber-sumber buku dan literatur terpercaya.

\section{HASIL DAN PEMBAHASAN}

Indomie Tempoe Doeloe dijual secara paket saat Jakarta Fair 2017 berlangsung. Paket terbagi menjadi dua, yaitu, paket besar dengan isi 10 bungkus Indomie tempo dulu dan paket kecil dengan isi 6 bungkus Indomie tempo dulu. Paket Indomie dikemas dengan menggunakan tote bag yang sangat menarik. Setelah acara Jakarta Fair selesai, Indomie Tempo Doeloe bisa didapatkan di gerai Indomaret dengan tote bag kecil dan berisi 5 bungkus Indomie Tempo Doeloe.

Pembahasan analisis kemasan Indomie Tempo Doeloe dilakukan berdasarkan teori daya tarik visual dan daya tarik praktis kemasan. Analisis tersebut akan terbagi menjadi dua, yaitu kemasan primer dan kemasan sekunder. 


\section{Analisis Kemasan Primer}

- Indomie Kuah Rasa Kaldu Ayam

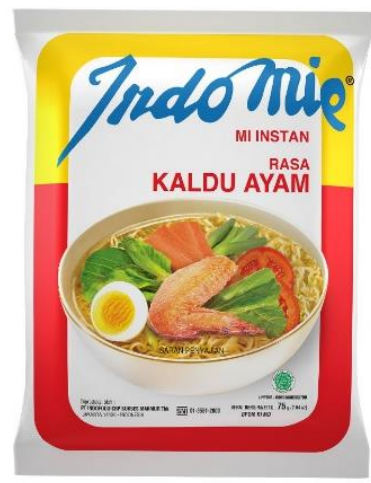

\section{Gambar 3 Kemasan Indomie Kuah Rasa Kaldu Ayam Tempo Doeloe (Sumber: Data Internet, 2017)}

1. Daya Tarik Visual

a. Warna

Warna yang digunakan pada kemasan ini adalah warna primer yang mencolok dan menarik.

Menurut C.S. Jones dalam artikel Anything But Neutral: Using Color to Create Emotional Images, dikatakan bahwa warna merah merupakan warna yang beraura kuat, berenergi dan melambangkan kegembiraan. Warna merah juga dipercaya dapat memberikan efek penambah nafsu makan. Warna kuning memberi kesan kehangatan dan rasa bahagia, selain itu warna kuning mencerminkan keceriaan dan semangat.

b. Bentuk

Konsep kemasan Indomie iini adalah kemasan sekali pakai. Kemasan berukuran 11 x 14,5 x $3,5 \mathrm{~cm}$ dengan bentuk vertikal. Sederhana dan memiliki ukuran yang pas untuk digengam.

c. Merek/Logo

Merek yang terpampang pada kemasan ini adalah logo merek Indomie. Penempatan logo terlihat jelas dan dominan pada sisi atas kemasan dengan keterbacaan yang baik dan menjelaskan secara langsung bahwa produk ini merupakan produk orisiinil dan asli dari merek Indomie.

d. Ilustrasi

Ilustrasi pada kemasan Indomie Tempo Doeloe ini menggunakan ilustrasi foto. Foto yang ditampilkan pada kemasan membuat konsumen tergiur dengan produk Indomie. Selain itu, ilustrasi foto produk merupakan penggambaran saran penyajian produk.

e. Huruf/Tipografi

Tipografi yang digunakan pada kemasan ini adalah jenis sen serif sehingga memiliki tingkat keterbacaan yang baik. Ukuran yang digunakan juga cukup baik.

f. Tata Letak

Diliihat dari segi PDP (Primary Display Panel) kemasan sudah disertai dengan informasi yang lengkap dan cukup baik. Namun, penempatan teks bagian atas terlihat terlalu berdekatan sehingga kurang terlihat penenkanannya.

2. Daya Tarik Praktis

a. Faktor Pengamanan

Kemasan cukup baik melindungi isi produk. Kemasan terbuat dari plastik yang kedap sehingga isi produk tahan terhadap air dan udara yang dapat merusak isi produk.

b. Faktor Ekonomi

Kemasan menggunakan plastik yang walaupun sekali pakai namun tetap ekonomis dalam perhitungan biaya produksi.

c. Faktor Distribusi

Kemasan mudah pendistribusian produk. Bentuk dan ukuran kemasan telah dirancang untuk tidak menyulitkan peletakan di rak 
ataupun tempat pemajangan produk.

d. Faktor Komunikasi

Kemasan Indomie Tempo

Doeloe ini juga sudah cukup baik dari segi komunikasinya. Kemasan cukup mencerminkan citra produk, mudah dipahami dan diingat oleh pelanggan.

e. Faktor Ergonomi

Kemasan memiliki faktor ergonomi yang baik. Kemasan memiliki ukuran yang mudah untuk dipegang, diambi dan dibawa. Selain itu kemasan juga cukup mudah untuk dibuka.

f. Faktor Identitas

Identitas produk dapat dengan mudah dikenali melalu kemasan. Warna yang digunakan cukup mecolok serta logo atau merek ditampilkan dibagian atas dengan ukuran yang besar.

g. Faktor Promosi

Dalam segi promosi, kemasan telah mempromosikan produk dengan baik. Menyertakan ilustrasi produk akan menambah ketertarikan konsumen dalam memilih produk.

h. Faktor Lingkungan

Sayangnya dalam segi lingkungan, kemasan belum termasuk dalam kategori ramah lingkungan karena menggunakan plastik yang berbahan dasar sulit untuk terurai.

- Indomie Kuah Rasa Kari Ayam

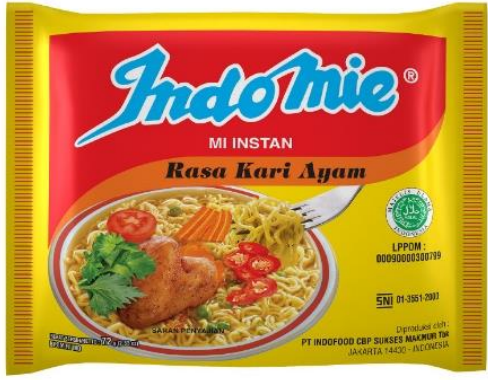

\section{Gambar 4 Kemasan Indomie Kuah Rasa Kari Ayam Tempo Doeloe \\ (Sumber: Data Internet, 2017)}

1. Daya Tarik Visual

a. Warna

Menurut C.S. Jones dalam artikel Anything But Neutral: Using Color to Create Emotional Images, warna kuning adalah warna yang menarik, memberikan kesan ceria dan semangat selain itu, warna kuning menggambarkan isi produk.

b. Bentuk

Konsep kemasan Indomie iini adalah kemasan sekali pakai. Kemasan berukuran 14,5 x $11 \mathrm{x}$ $3,5 \mathrm{~cm}$ dengan bentuk horisontal. Sederhana dan memiliki ukuran yang pas untuk digenggam.

c. Merek/Logo

Merek yang terpampang pada kemasan ini adalah logo merek Indomie. Penempatan logo terlihat jelas dan dominan pada sisi atas kemasan dengan keterbacaan yang baik dan menjelaskan secara langsung bahwa produk ini merupakan produk orisiinil dan asli dari merek Indomie.

d. Ilustrasi

Ilustrasi pada kemasan Indomie

Tempo Doeloe ini menggunakan ilustrasi foto. Foto yang ditampilkan pada kemasan membuat konsumen tergiur dengan produk Indomie. Selain itu, ilustrasi foto produk 
merupakan penggambaran saran penyajian produk.

e. Huruf/Tipografi

Tipografi yang digunakan pada kemasan ini adalah jenis serif dan sen serif sehingga memiliki tingkat keterbacaan dan penekanan yang baik. Ukuran yang digunakan juga cukup baik.

f. Tata Letak

Diliihat dari segi PDP (Primary Display Panel) kemasan sudah disertai dengan informasi yang lengkap dan cukup baik. Penggunaan jenis huruf serif dan san-serif membuat perbedaan dan penekanan informasi terlihat jelas.

2. Daya Tarik Praktis

a. Faktor Pengamanan

Kemasan cukup baik melindungi isi produk. Kemasan terbuat dari plastik yang kedap sehingga isi produk tahan terhadap air dan udara yang dapat merusak isi produk.

b. Faktor Ekonomi

Kemasan menggunakan plastik yang walaupun sekali pakai namun tetap ekonomis dalam perhitungan biaya produksi.

c. Faktor Distribusi

Kemasan mudah pendistribusian produk. Bentuk dan ukuran kemasan telah dirancang untuk tidak menyulitkan peletakan di rak ataupun tempat pemajangan produk.

d. Faktor Komunikasi

Kemasan Indomie Tempo Doeloe ini juga sudah cukup baik dari segi komunikasinya. Kemasan cukup mencerminkan citra produk, mudah dipahami dan diingat oleh pelanggan.

e. Faktor Ergonomi

Kemasan memiliki faktor ergonomi yang baik. Kemasan memiliki ukuran yang mudah untuk dipegang, diambi dan dibawa. Selain itu kemasan juga cukup mudah untuk dibuka.

f. Faktor Identitas

Identitas produk dapat dengan mudah dikenali melalu kemasan. Warna yang digunakan cukup mecolok serta logo atau merek ditampilkan dibagian atas dengan ukuran yang besar.

g. Faktor Promosi

Dalam segi promosi, kemasan telah mempromosikan produk dengan baik. Menyertakan ilustrasi produk akan menambah ketertarikan konsumen dalam memilih produk.

h. Faktor Lingkungan

Sayangnya dalam segi lingkungan, kemasan belum termasuk dalam kategori ramah lingkungan karena menggunakan plastik yang berbahan dasar sulit untuk terurai.

- Indomie Mi Goreng

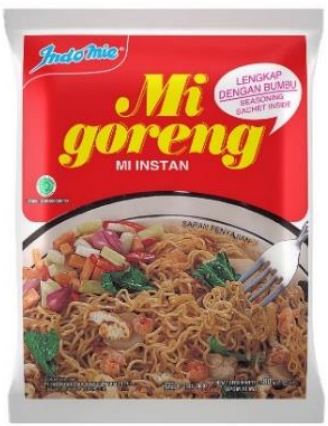

\section{Gambar 5 Kemasan Indomie Mi Goreng Tempo Doeloe \\ (Sumber: Data Internet, 2017)}

1. Daya Tarik Visual

a. Warna

Menurut C.S. Jones dalam artikel Anything But Neutral: Using Color to Create Emotional Images, warna merah merupakan warna yang beraura kuat, berenergi dan melambangkan kegembiraan. 
Warna merah juga dipercaya dapat memberikan efek penambah nafsu makan.

b. Bentuk

Konsep kemasan Indomie iini adalah kemasan sekali pakai. Kemasan berukuran $11 \times 14,5 \mathrm{x}$ $3,5 \mathrm{~cm}$ dengan bentuk vertikal. Sederhana dan memiliki ukuran yang pas untuk digengam.

c. Merek/Logo

Merek yang terpampang pada kemasan ini adalah logo merek Indomie. Penempatan logo terlihat jelas walaupun diletakan di bagian kiri atas dengan keterbacaan yang baik dan menjelaskan secara langsung bahwa produk ini merupakan produk orisiinil dan asli dari merek Indomie.

d. Ilustrasi

Ilustrasi pada kemasan Indomie Tempo Doeloe ini menggunakan ilustrasi foto. Foto yang ditampilkan pada kemasan membuat konsumen tergiur dengan produk Indomie. Selain itu, ilustrasi foto produk merupakan penggambaran saran penyajian produk.

e. Huruf/Tipografi

Tipografi yang digunakan pada kemasan ini adalah jenis sen serif sehingga memiliki tingkat keterbacaan yang baik. Ukuran yang digunakan juga cukup baik.

f. Tata Letak

Diliihat dari segi PDP (Primary Display Panel) kemasan sudah disertai dengan informasi yang lengkap dan cukup baik.

2. Daya Tarik Praktis

a. Faktor Pengamanan

Kemasan cukup baik melindungi isi produk. Kemasan terbuat dari plastik yang kedap sehingga isi produk tahan terhadap air dan udara yang dapat merusak isi produk.

b. Faktor Ekonomi
Kemasan menggunakan plastik yang walaupun sekali pakai namun tetap ekonomis dalam perhitungan biaya produksi.

c. Faktor Distribusi

Kemasan mudahkan pendistribusian produk. Bentuk dan ukuran kemasan telah dirancang untuk tidak menyulitkan peletakan di rak ataupun tempat pemajangan produk.

d. Faktor Komunikasi

Kemasan Indomie Tempo Doeloe ini juga sudah cukup baik dari segi komunikasinya. Kemasan cukup mencerminkan citra produk, mudah dipahami dan diingat oleh pelanggan.

e. Faktor Ergonomi

Kemasan memiliki faktor ergonomi yang baik. Kemasan memiliki ukuran yang mudah untuk dipegang, diambi dan dibawa. Selain itu kemasan juga cukup mudah untuk dibuka.

f. Faktor Identitas

Identitas produk dapat dengan mudah dikenali melalu kemasan. Warna yang digunakan cukup mecolok serta logo atau merek ditampilkan dibagian atas dengan ukuran yang besar.

g. Faktor Promosi

Dalam segi promosi, kemasan telah mempromosikan produk dengan baik. Menyertakan ilustrasi produk akan menambah ketertarikan konsumen dalam memilih produk.

h. Faktor Lingkungan

Sayangnya dalam segi lingkungan, kemasan belum termasuk dalam kategori ramah lingkungan karena menggunakan plastik yang berbahan dasar sulit untuk terurai. 


\section{Analisis Kemasan Sekunder}

- Tote Bag Kaldu Ayam

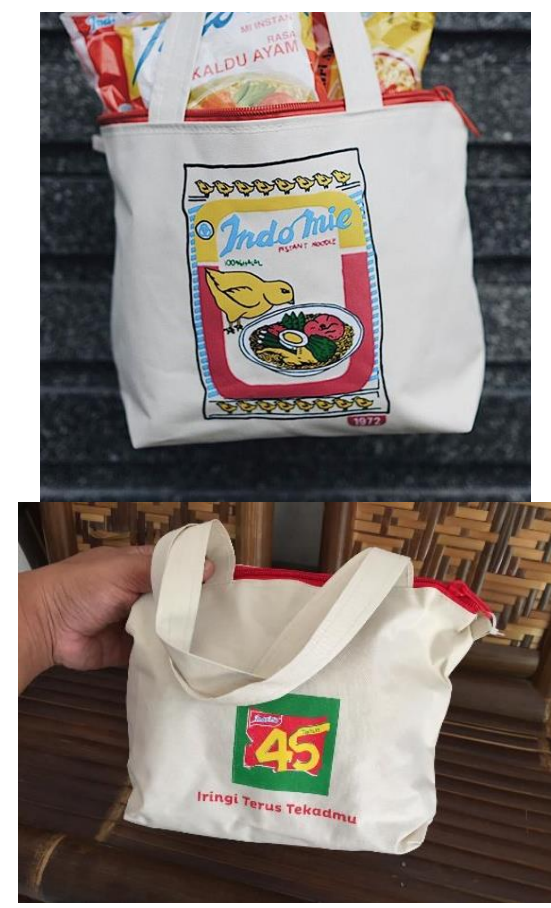

Gambar 6 Tote Bag Indomie Kuah Rasa Kaldu Ayam Tempo Doeloe

(Sumber: Data Internet, 2017)

1. Daya Tarik Visual

a. Warna

Warna yang digunakan pada kemasan ini adalah warna yang digunakan pada kemasan primer Indomie Kuah Rasa Kaldu Ayam. Warna primer yang digunakan membuat ilustrasi kemasan terlihat mencolok namun tetap sesuai dan serasi.

b. Bentuk

Kemasan terbagi menjadi 2 ukuran, yaitu tote bag besar dan tote bag kecil. Tote bag besar berbentuk persegi panjang dengan isi 10 bungkus Indomie. Tote bag kecil berbentu trapesium dengan isi 5-6 bungkus Indomie.

c. Merek

Merek yang terpampang pada kemasan ini adalah logo merek
Indomie. Penempatan logo terlihat jelas dan dominan pada sisi atas kemasan dengan keterbacaan yang baik dan menjelaskan secara langsung bahwa produk ini merupakan produk orisiinil dan asli dari merek Indomie.

d. Ilustrasi

Ilustrasi yang digunakan diambil dari ilustrasi Indomie Kuah Rasa Kaldu Ayam yang dibuat dengan gaya ilustrasi tangan untuk memberikan kesan tempo doeloe yang lebih terasa.

e. Huruf

Tipografi yang digunakan bergaya tulisan tangan untuk memberikan kesan buatan tangan yang orisinil.

f. Tata Letak

Pada bagian depan tote bag terdapat ilustrasi ilustrasi Indomie Kuah Rasa Kaldu Ayam sedangkan di bagian belakang tote bag terdapat ilustrasi khusus untuk memperingati HUT Indomie ke-45.

\section{Daya Tarik Praktis}

a. Faktor Pengamanan

Kemasan cukup baik melindungi isi produk. Kemasan terbuat dari bahan kain kanvas yang kuat tidak mudah rusak sehingga isi produk tidak akan bocor dan terlindung dari benda yang dapat merusak isi produk.

b. Faktor Ekonomi

Kemasan dibuat menggunakan bahan yang tebal dan bagus sehingga dari segi produksi kemasan mengeluarkan biaya yang cukup tinggi. Namun, karena kemasan tote bag ini adalah kemasan khusus dengan edisi terbatas, kemasan ini menjadi nilai jual tersendiri bagi produk.

c. Faktor Distribusi 
Kemasan tote bag memudahkan pendistribusian dan konsumen membawa produk. Bentuk dan ukuran kemasan telah dirancang untuk tidak menyulitkan peletakan di rak ataupun tempat pemajangan produk.

d. Faktor Komunikasi

Kemasan mengkomunikasikan merek dengan baik. Logo Indomie ditempatkan pada bagian atas ilustrasi sehingga nampak menonjol dan menarik.

e. Faktor Ergonomi

Kemasan memiliki faktor ergonomi yang baik. Kemasan memiliki ukuran yang mudah untuk dipegang, diambil dan dibawa. Selain itu jika produk telah habis, kemasan juga dapat digunakan kembali untuk membawa keperluan seharihari dan menjadi sarana promosi ditengah masyarakat.

f. Faktor Identitas

Identitas produk dapat dengan mudah dikenali melalu kemasan. Warna yang digunakan cukup mecolok serta logo atau merek ditampilkan dibagian atas dengan ukuran yang besar. Indentitas logo juga terdapat dibagian belakang kemasan tote bag.

g. Faktor Promosi

Kemasan memiliki keunikan tersendiri dengan jumlah yang terbatas sehingga menjadi sarana promosi yang baik dalam meningkatkan penjualan produk Indomie.

h. Faktor Lingkungan

Kemasan terbuat dari kain dan dapat digunakan berulangulang.
- $\quad$ Tote Bag Mi Goreng

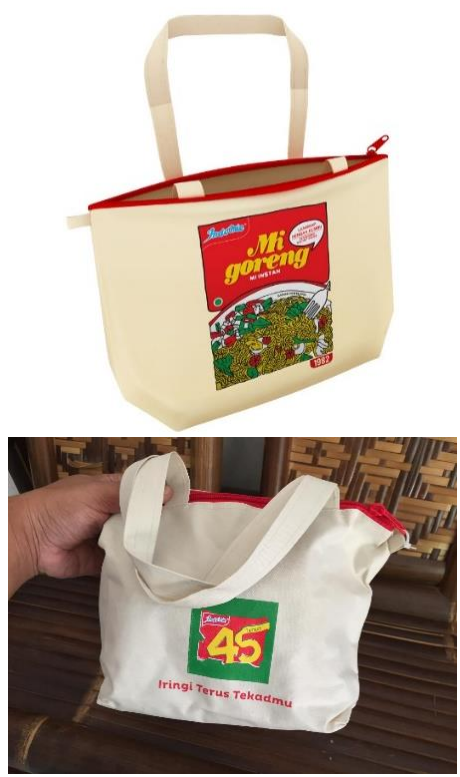

Gambar 7 Tote Bag Indomie Mi Goreng Tempo Doeloe (Sumber: Data Internet, 2017)

1. Daya Tarik Visual

a. Warna

Warna yang digunakan pada kemasan ini adalah warna yang digunakan pada kemasan primer Indomie $\mathrm{Mi}$ Goreng. Warna primer yang digunakan membuat ilustrasi kemasan terlihat mencolok namun tetap sesuai dan serasi.

b. Bentuk

Kemasan terbagi menjadi 2 ukuran, yaitu tote bag besar dan tote bag kecil. Tote bag besar berbentuk persegi panjang dengan isi 10 bungkus Indomie. Tote bag kecil berbentu trapesium dengan isi 5-6 bungkus Indomie.

c. Merek

Merek yang terpampang pada kemasan ini adalah logo merek Indomie. Penempatan logo terlihat jelas walaupun diletakan di bagian kiri atas dengan keterbacaan yang baik dan menjelaskan secara langsung bahwa produk ini 
merupakan produk orisiinil dan asli dari merek Indomie.

d. Ilustrasi

Ilustrasi yang digunakan diambil dari ilustrasi Indomie Mi Goreng yang dibuat dengan gaya ilustrasi tangan untuk memberikan kesan tempo doeloe yang lebih terasa.

e. Huruf

Tipografi yang digunakan bergaya tulisan tangan untuk memberikan kesan buatan tangan yang orisinil.

f. Tata Letak

Pada bagian depan tote bag terdapat ilustrasi ilustrasi Indomie Mi Goreng sedangkan di bagian belakang tote bag terdapat ilustrasi khusus untuk memperingati HUT Indomie ke-45.

2. Daya Tarik Praktis

a. Faktor Pengamanan

Kemasan cukup baik melindungi isi produk. Kemasan terbuat dari bahan kain kanvas yang kuat tidak mudah rusak sehingga isi produk tidak akan bocor dan terlindung dari benda yang dapat merusak isi produk.

b. Faktor Ekonomi

Kemasan dibuat menggunakan bahan yang tebal dan bagus sehingga dari segi produksi kemasan mengeluarkan biaya yang cukup tinggi. Namun, karena kemasan tote bag ini adalah kemasan khusus dengan edisi terbatas, kemasan ini menjadi nilai jual tersendiri bagi produk.

c. Faktor Distribusi

Kemasan tote bag memudahkan pendistribusian dan konsumen membawa produk. Bentuk dan ukuran kemasan telah dirancang untuk tidak menyulitkan peletakan di rak ataupun tempat pemajangan produk. d. Faktor Komunikasi

Kemasan mengkomunikasikan merek dengan baik. Logo Indomie ditempatkan pada bagian atas ilustrasi sehingga nampak menonjol dan menarik.

e. Faktor Ergonomi

Kemasan memiliki faktor ergonomi yang baik. Kemasan memiliki ukuran yang mudah untuk dipegang, diambil dan dibawa. Selain itu jika produk telah habis, kemasan juga dapat digunakan kembali untuk membawa keperluan seharihari dan menjadi sarana promosi ditengah masyarakat.

f. Faktor Identitas

Identitas produk dapat dengan mudah dikenali melalu kemasan. Warna yang digunakan cukup mecolok serta logo atau merek ditampilkan dibagian atas dengan ukuran yang besar. Indentitas logo juga terdapat dibagian belakang kemasan tote bag.

g. Faktor Promosi

Kemasan memiliki keunikan tersendiri dengan jumlah yang terbatas sehingga menjadi sarana promosi yang baik dalam meningkatkan penjualan produk Indomie.

h. Faktor Lingkungan

Kemasan terbuat dari kain dan dapat digunakan berulangulang.

\section{SIMPULAN}

Dapat disimpulkan bahan kemasan Indomie Tempo Doeloe memiliki daya tarik visual dan daya tarik praktis yang tergolong baik. Dari sisi visual, kemasan ini telah berhasil menarik perhatian konsumen dengan konsep tempo dulu. Sedangkan dari sisi fungsional, secara keseluruhan telah dipertimbangkan secara baik dengan kualitas, ukuran dan porsi yang pas dengan produk. Konsep Indomie Tempo Doeloe ini berhasil menjankau perhatian konsumen karena menarik dan unik, berbeda dengan 
produsen mi instan lainnya. Dengan diluncurkannya Indomie Tempo Doeloe ini konsumen terlihat antusias dan tertarik dengan produk. Penjualannya pun baik karena produk selalu habis terjual.

Peneliti berharap di masa yang akan datang akan banyak bermunculan seri kemasan baru yang unik dengan ide-ide kreatif untuk memberikan warna baru pada industri pengemasan di Indonesia.

\section{DAFTAR PUSTAKA}

Calver, Giles. 2007. What Is Packaging Design. Switzerland: Rotovision.

Cenadi, Christine Suharto. 1999. Elemenelemen dalam Desain Komunikasi Visual. Jakarta: Nirmana.
Julianti, Sri. 2014. The Art of Packaging. Jakarta: PT Gramedia Pustaka Utama.

Klimchuk, Marianne dan Sandra A. Krasovec. 2006. Desain Kemasan. Jakarta: Erlangga

Pujiriyanto. 2005. Desain Grafis Komputer. Yogyakarta: CV Andi Offset.

Porter, Michael E. 1998. From Competitive Advantage to Corporate Strategy. Harvard Business Review.

Sumber Lainnya:

Jones, C.S. (2015), “Anything But Neutral: Using Color to Create Emotional Images".Website:

photography.tutplus.com (Diakses 2 September 2017) 